\title{
Formação de espectadores na escola: mediações e desdobramentos estéticos do espetáculo "Axé Nzinga"
}

Spectatorship formation at school: mediations and aesthetic unfoldings of the spectacle "Axé Nzinga"

Martha Lemos de Moraes ${ }^{1}$ 


\section{Resumo}

Este artigo apresenta a descrição e análise das mediações realizadas com estudantes espectadores do Centro de Ensino Médio Urso Branco (Núcleo Bandeirante - Brasília/DF) a partir da recepção teatral de "Axé Nzinga", de Jonas Sales, em 2017, no auditório da escola. Apresenta o contexto escolar, a sinopse do espetáculo e as mediações realizadas pelo ator, pela professora de Arte e pelos graduandos bolsistas do PIBID-Teatro da Universidade de Brasília. Propõe um diálogo entre a Pedagogia da Autonomia (Freire, 2006), - Método Recepcional (Aguiar e Bordini, 1993), a Pedagogia do Espectador (Desgranges, 2015) e a Estética do Oprimido (Boal, 2009), em prol da ampliação de leitura de mundo dos estudantes-espectadores. Encontra neste diálogo caminhos possiveis para a emancipação de espectadores oprimidos.

Palavras-chave: Pedagogia do teatro; espectador; mediação; oprimido; escola

\section{Abstract}

This article presents a description and analysis of mediations developped with students spectators at Centro de Ensino Médio Urso Branco (Núcleo Bandeirante - Brasília ( DF) starting from the theatre audience reponse to "Axé Nzinga" by Jonas Sales in 2017, at the school's auditorium. It deals with the school context, the spectacle s overview as well as mediations performed by the actor, by the Arts professor and undergraduate students honored with PIBID-Theatre scholarships of Universidade de Brasilia. It presents a dialogue between Pedagogy of Autonomy (Freire, 2006), the Receptional Method (Aguiar and Bordini, 1993), The Pedagogy of the Spectator (Desgranges, 2015) and the Aesthetics of the Oppressed (Boal, 2009), so as to broaden the literature of the word of student-spectators. This dialogue points to possible paths in the emancipation of oppressed spectators.

Keywords: Theater pedagogy; spectator; mediation; oppressed; school 
A partir de um "olhar de dentro" da escola, como professora-pesquisadora de Arte no Centro de Ensino Médio Urso Branco (Secretaria de Estado de Educação Regional de Ensino Núcleo Bandeirante - Brasília/DF), professora-supervisora do PIBID - Programa Institucional de Bolsas de Iniciação à Docência e doutoranda na USP em Pedagogia do Teatro, apresento neste artigo a descrição e análise das mediações realizadas em "Axé Nzinga", espetáculo teatral apresentado por Jonas Sales em outubro de 2017 no auditório da escola.

Esta análise é parte de minha pesquisa de doutorado em andamento, que investiga caminhos possíveis para a formação de espectadores teatrais na educação escolarizada. Percebo a escola pública, em tempos sombrios pós-golpe parlamentar, por um lado, como uma lupa da sociedade, onde os problemas políticos/sociais/ histórico/culturais atuais se dilatam, escancarando a olho nu pensamentos/comportamentos fundamentalistas, fascistas, que envolvem a intolerância, a alienação e o preconceito; e por outro, como um potente lugar de resistência cultural: pela possibilidade de troca, dialogismo, alteridade, afeto, devir, saber sensível, pensamento crítico e leitura de mundo.

Em 2017 pude contar com a parceria de cinco bolsistas graduandos(as) em Artes Cênicas pelo PIBID-Teatro. Experimentamos com seis turmas de nono ano uma atualização do Método Recepcional (Aguiar e Bordini, 1993) como estratégia metodológica de ensino de Teatro, em diálogo com a Pedagogia do Espectador (Desgranges, 2015) e a Estética do Oprimido (Boal, 2009), em prol da formação de espectadores e da ampliação de leitura de mundo dos(das) estudantes.

O Método Recepcional, difundido pela Pedagogia da Literatura, "funda-se na atitude participativa do aluno em contato com os diferentes textos" (Bordini e Aguiar, 1993, p. 85). Trata-se de uma proposta pedagógica fundamentada na Estética da Recepção (Jauss, 1994), criada em princípio para a formação de estudantes-leitores(as) de obras literárias. Conforme Maria Bordini e Vera Aguiar (1993), os objetivos propostos pelo método incluem: efetuar leituras compreensivas e críticas; ser receptivo a novos textos e a leituras de outrem; questionar as leituras efetuadas em relação a seu próprio horizonte cultural (horizonte de expectativas); transformar os próprios horizontes de expectativas, bem como os do(a) professor(a), da escola, da comunidade familiar e social. As etapas do método consistem na sondagem, atendimento, ruptura, questionamento e culminam na ampliação de horizontes de expectativas, resultante dessa reflexão sobre as relações entre leitura e vida. A partir do trabalho realizado, os(as) alunos(as) percebem-se aptos para a busca de novos textos, que atendam a suas expectativas ampliadas, pois "o final dessa etapa é o início de uma nova aplicação do método, que evolui em espiral, sempre permitindo uma postura mais consciente com relação à literatura e à vida" (Bordini e Aguiar, 1993, p. 91).

A Pedagogia do Espectador (Desgranges, 2015) consiste em uma pedagogia teatral que busca compreender e potencializar o ato de leitura cênica do(a) espectador(a) de teatro. Fundamenta-se, como método de análise, na Estética da Recepção (Jauss, 1994; Iser, 1996), quando defende que o acontecimento estético se concretiza no processo de leitura, e o(a) leitor(a) se constitui neste ato - que não é passivo. Analisa esta relação como dialógica: uma "via de mão dupla" a partir da fricção entre 
produção e recepção, numa perspectiva que é ao mesmo tempo formal e histórica e, por isso, deve ser analisada no confronto entre ambas. Salienta que o ato de leitura contribui para que a experiência estética aconteça na recepção teatral, portanto, é potencialmente pedagógico. Ou seja, a experiência estética não existe sem a atuação do(a) leitor(a) e sem sua disponibilidade à produção de sentidos (a priori inexistentes), neste caso, relacionados à aprendizagem da linguagem teatral. Assim, a experiência estética almejada pode ser potencializada a partir do diálogo entre uma proposição estimulante e um(a) participante disponível (Desgranges, 2014).

Porém, essa disponibilidade solicitada pela leitura cênica não é inerente ao espectador ou espectadora: "[...] não parece evidente, e que não pode ser compreendida como um talento natural, mas sim como uma conquista cultural" (Desgranges, 2015 , p. 21). O acontecimento teatral solicita a instauração de outra lógica espaço-temporal, interrompendo o ritmo cotidiano, fundando um espaço para a necessária participação do espectador, que lê simbolicamente. Nessa perspectiva que ações pedagógicas/culturais de mediação teatral podem potencializar essa relação entre ator/atriz e espectadores(as), cena de teatro e sala de espetáculo.

As práticas de mediação teatral compreendem não somente procedimentos artísticos e pedagógicos propostos diretamente aos espectadores iniciantes, mas abordam a formação de espectadores com uma questão que abrange as diversas etapas do evento teatral desde a concepção artística até sua recepção pelo público. É considerado procedimento de mediação toda e qualquer ação que se interponha, situando-se no espaço existente entre o palco e a plateia, buscando possibilitar ou qualificar a relação do(a) espectador(a) com a obra teatral (Desgranges, 2008, p. 53). A perspectiva dos Ensaios de Desmontagem proposta pelo autor como estratégia de mediação teatral está apoiada "na ideia de se efetivar uma arte do espectador, tratando este como um artista em processo, propondo-lhe jogos de improvisação semelhantes aos desenvolvidos pelo grupo teatral durante a montagem" (Desgranges, 2011, p.81). Pressupõe "a implementação de procedimentos que tornem os participantes aptos para interpretar (compreender artisticamente), tal como os artistas implementam procedimentos para interpretar (conceber artisticamente)" (Desgranges, 2011, p. 81). Denomina os ensaios de desmontagem como "ensaios de preparação" quando antecedem a recepção, e "ensaios de prolongamento", aquelas realizadas em desdobramentos posteriores.

"A estética do Oprimido", último livro de Augusto Boal (2009, p. 132), é defendida pelo autor como "a estética dos direitos humanos" e explica: "trata-se de ir além, à raiz, ao âmago do ser humano e revelá-lo. Essa revelação surge em forma estética, através da arte. Como trabalhamos com oprimido, aí surge a Estética do Oprimido" (2009, p. 137). Boal salienta que é pela posse da Palavra, da Imagem e do Som que os opressores oprimem: "Imagem, palavra e som não circulam livres na sociedade são canalizados pelas estações de rádio e tv, pelos livros, revistas e jornais, escolas e universidades, e pela propaganda na beira da estrada. Tudo isso tem dono!" (2009, p. 136). Defende que temos que reconquistar palavra, imagem e som por meio da sinestesia (diálogo entre os sentidos), uma vez que nosso corpo se mecaniza nas ações dos rituais cotidianos. "Não basta aprender a ler e escrever. É preciso sentir, ver e 
ouvir, produzir imagens, palavras e sons" (2009, p. 94). Logo, pela Estética do Oprimido, estimula-se a inter-relação do pensamento sensível e do pensamento simbólico, possibilitando que o sujeito produza e leia metáforas².

As aproximações entre o método recepcional, a pedagogia do espectador e a estética do oprimido partem do sentido freireano de leitura de mundo: "a leitura não se esgota na decodificação pura da palavra escrita ou da linguagem escrita, mas se antecipa e se alonga na inteligência do mundo. A leitura do mundo precede sempre a leitura da palavra e a leitura desta implica a continuidade da leitura daquele" (Freire, 1989, p.09).

Além disso, estes autores almejam não somente uma apropriação estética da arte, mas direta ou indiretamente pretendem a formação para a cidadania: seja pela ampliação de horizonte de expectativas, pela emancipação do espectador ou pela luta contra as opressões sociais.

Nessa perspectiva, por uma pedagogia teatral ao mesmo tempo estética/política/ pedagógica/social, sem dicotomia entre o fazer/fruir teatro, foi que realizamos este trabalho de formação de espectadores em 2017, e em especial, as mediações teatrais pré e pós espetáculo "Axé Nzinga", de Jonas Sales, em outubro (início do 4o Bimestre letivo). Tratou-se da segunda recepção teatral de espetáculo profissional realizado na escola em 2017, precedido por "Chá de Cartas" de Rayssa Borges, realizado e mediado no final do 20 bimestre. No entanto, é importante salientar que desde o início do ano, a partir da diagnose das turmas pela "sondagem de horizonte de expectativas" (Aguiar e Bordini, 1993) e "mapa da situação" (Boal, 2009, p.217), de opressões vivenciadas pelos(as) alunos(as), foram realizadas ações voltadas para a formação de espectadores. Os Ensaios de Resistência Cultural ${ }^{3}$ foram intercalados a essas recepções de espetáculos profissionais ao longo de todo o ano, com ênfase no 10 e 20 bimestre; além da recepção e mediações teatrais do espetáculo "Lugar de Mulher é onde ela quiser"4, apresentado por alunas no final do 20 e no início do 30 bimestre em projeto extraclasse.

Desde o início dos ensaios de montagem (3o Bimestre), as turmas foram divididas em "elenco" e "equipe de encenação". Os(as) graduandos(as) bolsistas do PIBID ficaram responsáveis pelos grupos de elenco, que ensaiavam no auditório ou pátio da escola, enquanto eu conduzia as equipes de encenação em sala de aula. Quando agendamos Axé Nzinga para ser apresentado em 20 de outubro no auditório do CEM Urso Branco, estávamos no auge dos ensaios de um espetáculo por turma, para

\footnotetext{
${ }^{2}$ Noção boaleana de metáfora: "[...] transpõe algo que existe no contexto cotidiano para um contexto diferente - como palavra deslocada do seu texto para outro. Ou constrói, em outra substância imagens da realidade original, como um quadro ou uma estátua". O autor complementa: "é visão organizada do mundo - não é a coisa, é outra coisa: uma visão da coisa. E complementa: "a metáfora abrange todas as artes visuais, vivas em palco ou arena, documentadas em tela, fita ou foto, todas as artes sonoras, acústicas ou eletrônicas, todas as que já existem ou que venham a ser inventadas” (Boal, 2009, p. 120).

3 Proponho em minha tese os "ensaios de resistência cultural" como uma terceira categoria de ensaios de desmontagem. Trata-se de uma arte do espectador proposta por meio de jogos de improvisação, realizada mesmo quando não há a possibilidade de recepção de espetáculos. Esta arte do espectador é produzida a partir de outros estímulos estéticos do cotidiano ou possíveis de produzir em sala de aula, como pequenos vídeos, imagens, reportagens ou cenas de improvisação produzidas pelos alunos e alunas, que funcionam como dispositivo inventivo para a cena e vice versa, a fim de resistir à precariedade / sucateamento das escolas e à dificuldade de levar os estudantes ao teatro com frequência.

4 Resultado estético de oficina de montagem teatral oferecida pelo projeto interdisciplinar "Mulheres de Luta", realizado nos sábados letivos concomitantes ao segundo bimestre, como reposição das aulas "perdidas" durante a greve dos professores (10 Bimestre). A "Oficina de Teatra", foi conduzida por mim e ocorreu mediante inscrição prévia de meninas e meninos de 90 ano à 3a série do Ensino Médio. Como o espetáculo foi baseado no livro "para educar crianças feministas: um manifesto", de Chimamanda Ngozi Adichie (2017) e em relatos autobiográficos das alunas, o protagonismo de atuação foi dado somente às alunas. Os alunos compuseram a equipe de encenação (como cenógrafos, figurinistas, iluminadores, sonoplastas e maquiadores). 0 espetáculo foi apresentado para toda a escola.
} 
apresentação (e recepção) na "Il Mostra de Teatro dos 9os anos do Urso Branco 5", que seria realizada no final de novembro. Assim, teríamos tempo hábil de realizar dois encontros de mediação pré-espetáculo com cada turma. Um dos principais desafios era mediar "Axé Nzinga" sem interromper os ensaios de montagem, imbricar as montagens em andamento e a "desmontagem" (Desgranges, 2011) de "Axé Nzinga".

\section{Planejamento de mediações pré-espetáculo}

Utilizamos como material para planejamento coletivo a leitura do projeto (com ênfase na sinopse) disponibilizado pelo artista previamente e a filmagem do espetáculo $^{6}$ na íntegra. Além disso, eu e dois graduandos do PIBID já o havíamos assistido em temporada no Espaço Pé Direito - Vila Telebrasília - DF.

Conforme Jonas Sales (2017),

Axé Nzinga é uma proposta artística/cênica solo, em que o artista revela em seu corpo a "Corponegritude", resultado da aproximação com as técnicas das expressões populares de matrizes africanas tais como Maracatu, Congos e Maculelê, reverberando energias do universo de Nzinga, Rainha africana. Nesta experiência estética/cênica, se provoca o compartilhamento de uma corporeidade conectada com a atualidade, dialogando com os problemas sociopolíticos que permeiam as discussões de negritude, racismo, preconceito e papel da mulher na contemporaneidade. Canaliza-se no corpo do artista em cena o Axé (energia) que se propaga, em movimento, em poesia contida na história da mulher, da guerreira, da política e do mito Rainha Nzinga. Assim, foram partilhados com o público os saberes da tradição na contemporaneidade.

O espetáculo anuncia a história e a força dessa mulher, um dos mais importantes símbolos de resistência da luta contra a escravidão e segregação dos povos negros na África e que se mitifica em solo brasileiro. É um pressuposto essencial na criação de parâmetros de discussões estéticas e sociopolítico-culturais. Propiciar o encontro de sujeitos com a energia da Rainha Ginga é o eixo fundamental desta proposta cênica. Divide-se em 4 momentos que se interligam com diálogos de mulheres negras ${ }^{7}$ que se comunicam com o universo da rainha Nzinga:

Movimento 1 - O feminino Nzinga: Neste movimento será mostrada a energia do universo feminino contido na rainha Ginga. Ela se mostra sensual, sexual, amante, mãe. Ela é água, em ondulações, límpida. Fria e quente. É a rainha que sente amor, sensível, que deseja e quer prazer.

Movimento 2 - A Política Nzinga: Neste movimento será mostrada a energia, eficácia e articulação política que a rainha Ginga teve junto aos europeus. Ela é terra, é chão. A situação mostra-se em uma mesa de jantar, símbolo de reuniões, conchavos e imposição civilizatória da nobreza colonial europeia.

Movimento 3 - A Guerreira Nzinga: Neste terceiro movimento, a energia revelada será a da guerra, da rainha Ginga em Batalha. É fogo. Mostram-se as artimanhas e articulações guerreiras que a rainha Ginga veio a articular junto aos seus soldados. Revela a estrategista que não permitia a invasão dos europeus em seu território.

Movimento 4 - O Mito Nzinga: Neste instante mostra-se a rainha Ginga que atravessou o oceano e se torna um mito no Brasil e no mundo. Ela é o ar que se expande no universo. Ela é esperança, ela é crítica. Ela é etérea. (SALES, Sinopse de Axé Nzinga, 2017).

\footnotetext{
5 A Mostra de Teatro neste ano foi agregada à programação da Semana de Consciência Negra que acorreu no período de 20 a 28 de novembro. Tratou-se de projeto interdisciplinar que envolveu toda a escola

6 Disponivel em: https://www.youtube.com/watch?v=ljHh4BsBO6Y. Acesso em: 13 dez. 2019.

7 Esses diálogos foram coletados por meio de filmagem de entrevistas do ator com mulheres ativistas do Movimento Negro no DF, e essas vozes e narrativas foram inseridas em vídeo e/ou áudio durante o espetáculo, com autorização prévia das mesmas.
} 
No planejamento coletivo, além dos aspectos formais, debatemos sobre representatividade e lugar de fala a partir dos seguintes questionamentos: Por quê no espetáculo um ator (homem) representa uma mulher? Não estaria desta forma reforçando o silenciamento da mulher negra? Dar voz a uma mulher negra em cena para representar a rainha Nzinga não seria mais ético, já que ele trata justamente das questões raciais e de gênero no espetáculo? Mesmo sendo negro, que legitimidade ele possui para abordar questões relacionadas ao corpo feminino?

Conforme Djamila Ribeiro (2017, p. 68), “[...] certas identidades têm sido historicamente silenciadas e desautorizadas no sentido epistêmico, ao passo que outras são fortalecidas (p. 23). Trata-se do silêncio imposto para pessoas que foram colonizadas. "Os grupos oprimidos podem e devem falar por si". Neste sentido, consideramos que o diretor/ator perdeu a oportunidade de dar representatividade e protagonismo à mulher negra. Por outro lado, analisamos que a alternância entre ele e os vídeos/áudios das mulheres negras em cena o tira do lugar de "porta-voz" e o coloca em uma relação dialógica com narrativas legítimas que falam por si.

Além disso, Djamila Ribeiro (2017, p.75) alerta: "Um dos equívocos mais recorrentes que vemos acontecer é a confusão entre lugar de fala e representatividade [...]". Para autora, enquanto a representatividade diz respeito a invisibilidade, silenciamento e ausência das pessoas colonizadas/oprimidas em lugares de poder, o lugar de fala se refere a como a pessoa que fala se coloca eticamente a partir do lugar social que ela faz parte. Diferentes lugares sociais nos fazem ter experiências distintas e outras perspectivas. Assim, se a representatividade da mulher negra só é possível a partir da sua ocupação em lugares de poder e voz, insubstituível, o lugar de fala pode ser ocupado por todos:

[...] falar a partir de lugares é também romper com essa lógica de que somente os subalternos falem de suas localizações, fazendo com que aqueles inseridos na norma hegemônica sequer se pensem. Em outras palavras, é preciso cada vez mais, que homens brancos cis estudem branquitude, cisgeneridade, masculinos (Ribeiro, 2017, p.75).

Ou seja, o fundamental é que os indivíduos pertencentes ao grupo social privilegiado, em termos de locus social, "consigam enxergar as hierarquias produzidas a partir desse lugar e como esse lugar impacta diretamente na constituição dos grupos subalternizados" (Ribeiro, 2017, p. 77).

Acerca dessas diferenças, se por um lado o ator desliza na representatividade de gênero, por outro, assume ética/esteticamente o seu lugar de fala numa relação interseccional entre opressor e oprimido: enquanto homem, com identidade de gênero cis, professor universitário, com orientação sexual gay, artista, negro claro, potiguar/ brasileiro. Luíza Bairros (apud Ribeiro, 2017, p. 57) salienta que "as opressões agem de forma combinada", e que a mulher negra ocupa um lugar maior de vulnerabilidade. No entanto, defende que "não pode haver hierarquia de opressões, pois, sendo estruturais, não existe preferência de luta". Consideramos que essa tenha sido a perspectiva do diretor/ator, pois seu lugar de fala se evidenciou tanto esteticamente, pelo espetáculo, quanto em seu discurso no projeto/sinopse, que salienta a energia da rainha e não a sua personificação. 
Costa (2015, p. 146) alerta que os estereótipos pejorativos fazem parte da história recente das artes cênicas, cinema e televisão:

Práticas racistas como pessoas brancas ridicularizando pessoas negras, atores negros em papéis grotescos ou estereotipados como moleques levando cascudos ou carregando bandejas, negras lavando roupa ou esfregando o chão, mulatinhas se requebrando, domesticados Pai Joões e lacrimogêneas Mães Pretas.

No espetáculo Axé Nzinga, pelo contrário, o ator se coloca em cena sem se travestir da personagem ou estereotipá-la. Todos os seus figurinos mantêm ao menos metade de seu corpo nu, mostrando permanentemente suas formas masculinas. Seu rosto se mantém masculino, sem qualquer efeito que tente transformá-lo em feminino. O timbre de sua voz se mantém masculino. Seu gestual também não mimetiza o corpo das mulheres. Além disso, em grande parte das cenas ele se dirige aos espectadores em terceira pessoa, não como a personagem Nzinga, mas como um narrador/contador. A história da colonização é contada pelos olhos dos(as) africanos(as) que aqui chegaram e lá ficaram, como Nzinga, que é enaltecida como uma entidade: "Ginga nunca chegou em solo brasileiro, mas como tantas outras rainhas e deusas, foi guerreira, mulher, estadista, temida, valente. Foi ardor, paixão e ódio. Rainha imortal", ele diz em cena.

Conforme Costa (2015, p. 120),

É comum vermos o corpo negro esvaziado de sua história, de sua memória coletiva, de sua beleza, representado pejorativamente pela colonização de forma a fragilizar os sujeitos. Colocado para segurar a corda das agremiações carnavalescas de Salvador, o corpo coisificado é usado como barreira para dividir a multidão. Sem a consciência de sua identidade, sem conhecer sua história, sem a valorização de sua ancestralidade, esse sujeito negro está na linha tênue da incompreensão de si mesmo.

Em Axé Nzinga, a rainha é apresentada como uma bela mulher, estrategista política, guerreira, mito e símbolo de resistência. A riqueza da cultura afro-brasileira é valorizada em cena, por meio da música, da dança, dentre outros. Considerando este como um eixo de discussão, analisamos a recepção do espetáculo na escola como uma importante ação de valorização cultural, consciência negra e processo de empoderamento racial e de gênero, em especial para as alunas negras, e buscamos destacar essa questão nas mediações pré-espetáculo.

Definimos que, para os elencos, selecionaríamos um ângulo de ataque ${ }^{8}$ comum a todas as turmas: a vivência corporal das danças/músicas afro-brasileiras como ampliação de repertório estético/expressivo para a cena. Desta forma ao mesmo tempo valorizaríamos a cultura afro-brasileira e a aproveitaríamos como elemento de criação dos espetáculos. Segundo Boal (2009, p. 19), “Palavra, imagem e som, que hoje são canais de opressão, devem ser usados pelos oprimidos como formas de rebeldia e ação, não contemplação absorta. Não basta consumir cultura: é necessário produzi-la". A partir disso, cada graduando(a) pôde planejar as mediações pré-espetáculo à sua maneira.

\footnotetext{
8 Desgranges (2011) define ângulo de ataque como os elementos da linguagem teatral presentes na escrita cênica que podem ser selecionados pelo mediador como vetor de análise, tanto por terem se destacado no espetáculo, quanto por dialogarem com outras noções teatrais que estejam sendo trabalhadas pelo professor.
} 
Para as equipes de encenação, que estavam iniciando as elaborações de cenário, figurino, iluminação, maquiagem e sonoplastia, selecionei como ângulo de ataque a visualidade do espetáculo, com ênfase na indumentária. Não pretendia conduzir o olhar, mas estimular o "olho curioso" (Rogoff, 1998, p.18), análogo ao que Boal chama de olhar vendo 9 (Boal, 2009). Considerei que, tal como discutimos em planejamento, a riqueza de metáforas na visualidade dos figurinos poderia suscitar uma infinidade de leituras sobre a mulher negra. Esta também seria uma forma de resolver o desafio de, ao mesmo tempo, dar sequência aos trabalhos de montagem para a Mostra de Teatro (no caso, os estudos sobre figurino) e partilhar leituras cênicas metaforicamente.

\section{Mediações pré-espetáculo: Ensaios de Preparação}

Conforme relatado pelos(as) bolsistas do PIBID, foram realizados em suas turmas de elenco jogos brincantes de cocos de roda, cirandas e maracatus; ações físicas dos personagens a partir de matrizes de movimentos que surgiram em exercícios com essas danças/músicas; jogos e brincadeiras cantadas (com coros) como cenas de transição em algumas montagens. No entanto, irei me aprofundar na análise das mediações que realizei com as equipes de encenação as quais conduzi e coletei dados de pesquisa.

Na primeira aula-ensaio de preparação de Axé Nzinga organizei slides sobre "indumentária teatral", contextualizando sua funcionalidade na cena contemporânea, bem como os procedimentos de trabalho do figurinista; mostrei aos(às) alunos(as) imagens diversas do livro "Auleum"10 de José de Anchieta, com a demonstração dos desenhos seguidos de fotos dos figurinos prontos; comparei algumas imagens e solicitei a leitura visual dos alunos a partir de perguntas. Nesta exemplificação comparativa, incluí fotos do espetáculo "Axé Nzinga", antes mesmo de divulgar sua apresentação na escola.
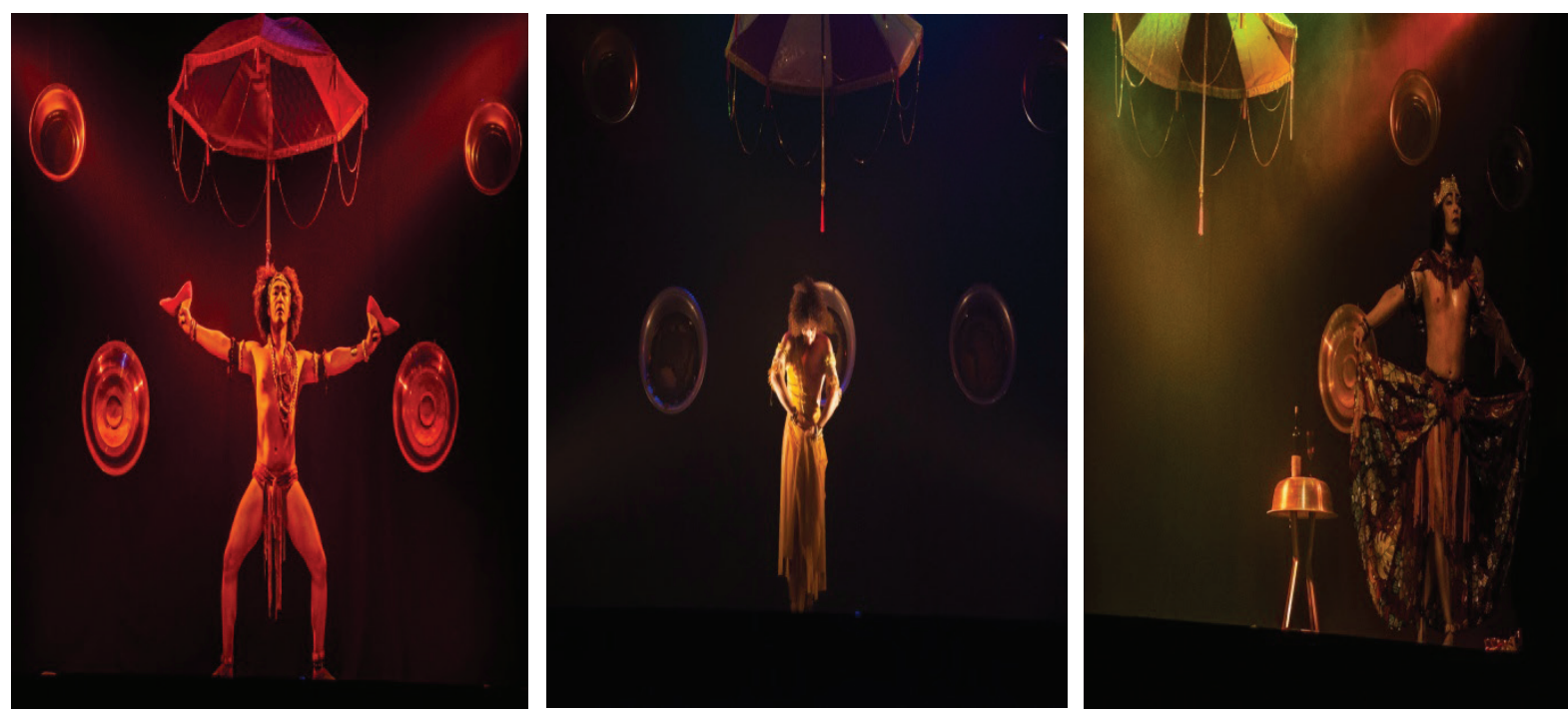

Fotos do espetáculo "Axé Nzinga" utilizadas em ensaio de preparação (créditos: Jemima Bracho)

\footnotetext{
9 Com a criação do Teatro Imagem, Boal buscou aperfeiçoar o sentido da visão, ampliando-o, dando significado às coisas que vemos. Ele diz que nossos olhos têm a prática do "olhar", mas não "ver". Na teoria dos Neourônios Estéticos (2009), salienta que nosso olho físico não faz as leituras metafóricas da aparência das coisas e situações de forma natural, que ficamos ligados ao externo e o que há por trás da imagem nos passa despercebido. Por este motivo, defende que essa visão pode ser exercitada, estimulada a partir de jogos da categoria "olhar vendo".
}

10 José de Anchieta Costa. Auleum: a quarta parede. São Paulo: Abooks, 2002. 
Inicialmente, poucos(as) alunos(as) verbalizavam suas leituras, que eram utilizadas como elo para eu lançar novas perguntas e fomentar a discussão. Conforme Freire (1996), "ninguém é autônomo para depois decidir. A autonomia vai se constituindo na experiência de várias, inúmeras decisões, que vão sendo tomadas (p. 107). Assim, busquei estabelecer um clima de "bate-papo", e aos poucos os(as) alunos(as) foram conquistando autonomia, ao se encorajarem a compartilhar suas interpretações.

Ao questionar a cor da pele do ator, responderam: "branca"; "negro"; "índio"; "moreno"; "pardo"; "não dá pra (sic) saber por causa da luz". A fim de introduzir o tema do espetáculo, aproveitei para perguntar: o que define a raça de uma pessoa? Vários falaram ao mesmo tempo. Algumas turmas começaram a discutir sobre cotas na Universidade e essa discussão rendeu até o final da aula. Em outras, consegui lançar outras perguntas como: Até que ponto terminologias utilizadas tais como "mulata" não reforçam o racismo? Já ouviram falar de "colorismo"? Por que se tenta "amenizar as negritudes" chamando negros de morenos? Será que este tipo de visão não enfraquece o Movimento Negro? Essa discussão, polêmica, rendeu até o final da aula.

$\mathrm{Na}$ leitura da terceira foto, todos(as) afirmaram se tratar de uma rainha (por causa da coroa). Questionei: e se não tivesse a coroa? "daí não", diziam. "Daí pareceria uma guerreira" ou "uma mulher qualquer" ou "uma mulher fazendo topless". Perguntei então se o figurino era "realista" ou "simbólico". Obtive respostas variadas, mas principalmente "realista, de época". Questionei: não seria possível ser de época sem ser realista? Estranharam e a maioria respondeu que não. Questionei: será que essa personagem de época fazia topless? Eles(as) riram e julgaram que não. Um aluno perguntou: "e por que ele não usou seios falsos então"? Devolvi a pergunta. Outra aluna respondeu: "então não é um figurino realista?" devolvi a pergunta. Fui devolvendo as perguntas até os(as) próprios alunos(as) começarem a refletir, argumentar e defender ideias, ou mesmo expandir suas percepções sobre aquelas imagens pela partilha de leituras. Freire (2006, p.107) salienta que "ninguém é sujeito da autonomia de ninguém", ou seja, como mediadora, dar respostas seria inútil. Seriam especulações sobre as minhas leituras, que em nada contribuiriam para a emancipação dos(as) estudantes-espectadores(as).

Aula seguinte. Era o segundo e último ensaio de preparação de Axé Nzinga, a uma semana do espetáculo. Mantendo o mesmo ângulo de ataque (Desgranges, 2011) da aula anterior neste encontro eu pretendia a leitura inventiva de figurinos/ personagens pelo fazer teatral adaptei um jogo de improvisação de Augusto Boal (2009), de construção de personagens sociais ${ }^{11}$, mas com ênfase na criação e leitura de figurinos:

Levei para a aula tecidos diversos (incluindo lençóis, toalhas de banho, lenços, toalhas de mesa, cortinas) e alguns acessórios como perucas, óculos, meias-calças, meias coloridas, bonecos, chapéus, narizes de palhaço, máscaras diversas e posicionei em "escambo" no centro de uma roda. Eles(as) também eram convocados(as) a contribuir: colocavam casacos, cachecóis, óculos, baralhos, toucas e bonés. Além

\footnotetext{
11 O autor defende: "Para que cumpra seus objetivos sociais, é importante enfatizar a função social opressora e não detalhes psicológicos" E salienta: "Não se deve construir personagens de uma só dimensão, mas, ao mesmo tempo, temos que ter cuidado para não absolvê-los tentando "humaniza-los" (Boal, 2009, p. 209).
} 
disso, incluí algumas folhas de papel em branco, pincéis hidrocor e fita crepe. Após um breve aquecimento em círculo, dividi a turma em duplas, intercalando em sequência quem seria número 1 (personagens) e quem seria número 2 (mestres figurinistas). Entreguei para cada figurinista um "papelzinho" escrito previamente um "personagem social" (busquei inserir personagens que dialogassem com a temática do espetáculo). Exemplos: negro jovem escravizado na colonização; negra idosa escravizada na colonização; rainha jovem africana (Nzinga); rainha criança Elisabeth (da Inglaterra); rei Salomão; homem colonizador europeu; homem negro jovem brasileiro atual; muIher branca jovem brasileira atual; senhora negra brasileira atual; homem negro gay; mulher negra trans; homem negro rico; homem negro pobre; mulher negra cantora famosa; homem negro jogador de futebol famoso; cachorro da rainha Elisabeth.

Os(as) alunos(as) que fariam as personagens sociais não poderiam ver "quem" eles(as) seriam: a instrução era que fossem tentando descobrir que grupo social eles representavam a partir da leitura do próprio figurino. Cada mestre figurinista pregou o "papelzinho" nas costas do(a) seu ou sua colega; criou um figurino e o(a) vestiu (a partir dos materiais disponíveis e do próprio entendimento sobre o que estava sugerido na descrição das personagens).

Os(as) mestres figurinistas se tornaram espectadores(as), sentados em semicírculo; e os(as) personagens sociais, andando pelo espaço, começavam a interagir com os demais, comportando-se como quem eles(as) suspeitavam representar. À medida que ele(a) fosse percebendo as reações dos demais personagens, deveria ir adequando o seu comportamento, a fim de aproximar-se cada vez mais do(a) próprio(a) personagem "às escuras". No final, todos deveriam sentar-se lado a lado e posicionar-se voluntariamente em ordem crescente de poder/status social que cada personagem julgava ter, do(a) mais oprimido(a) para o(a) mais opressor(a), tendo como referência a sociedade opressora e preconceituosa em que vivemos. Os seus papéis eram revelados e iniciávamos a discussão.

Durante o exercício, sempre vinham alunos(as) cochichar nos meus ouvidos: "professora, quem é Rainha Nzinga?" ou "eu não conheço a personagem (Nzinga), posso trocar o papelzinho"? Eu dizia que a regra não permitia. Que eles(as) deveriam tentar decifrar pelos outros adjetivos (rainha africana, por exemplo). Por fim, todas as turmas conseguiram realizar o jogo, mesmo quando não conheciam a personagem, ao mesmo tempo em que a curiosidade sobre a temática do espetáculo era provocada antes mesmo dele ser anunciado.

Inicialmente alguns reclamavam que não havia materiais suficientes no escambo para construir o figurino desejado. Eu respondia: "então crie o material! E lembre-se de que o figurino não precisa ser realista, vocês podem utilizar simbologias. Usem e abusem das metáforas! Assim, aos poucos iam surgindo figurinos criativos, como carta de baralho em forma de pirulito para representar a rainha Elisabeth criança; fantoche de mão feito de meia para representar o cachorro (um aluno utilizou uma meia preta por baixo de uma meia branca e cortou o local dos olhos e boca. As orelhinhas caídas eram as pontas da meia branca, que posta frouxa provocava o efeito de orelhas caídas); coroa feita de copo descartável desfiado; etc. 
Alguns estereótipos racistas surgiram no jogo, como o black face ${ }^{12}$. Mesmo não havendo tinta ou maquiagem, duas duplas em turmas diferentes reproduziram este efeito estereotipado: uma com máscara de meia calça preta e boca feita de apito lúdico em formato de boca e a outra, com máscara improvisada de fita isolante grudada na pele do rosto, utilizando a própria língua para simular a ampliação dos lábios e ridicularizar os fenótipos negros. Fiquei em dúvida se impedia durante o jogo ou se deixava seguir para fomentar a discussão no final. Na primeira turma, pega de surpresa, decidi permitir, pensando que poderia gerar uma discussão fértil sobre o racismo velado na própria turma. Mas a situação saiu do controle quando percebi que a reação risível dos colegas se transformou em reprodução do racismo em minha própria sala de aula. Acabei interrompendo o jogo de forma enérgica para chamar a atenção dos alunos e falar sobre o quanto black face é uma prática racista e pior, o quanto eles estavam sendo racistas ao achar graça. O que eu queria que virasse debate acabou virando autoritarismo da minha parte. Os(as) alunos(as) arregalaram os olhos e se calaram. Depois tentei retomar o jogo, mas não havia mais clima, a sequência da aula foi extremamente improdutiva.

Quando aconteceu a segunda black face, na turma seguinte, no mesmo dia, sem interromper o jogo eu abordei a dupla específica, expliquei que era uma prática racista que ridiculariza o negro e orientei que mudassem a proposta. Nesta turma eu consegui levantar o debate de forma dialógica no final, o que foi produtivo. Discutimos os limites entre liberdade de expressão e crime, tendo em vista que racismo é crime. Uma aluna sugeriu: "professora, por que você não distribui então os papéis de negros para alunos negros e papéis de brancos para alunos brancos?".

Esta sugestão quebrou meus paradigmas. Sempre defendia para os meus alunos e alunas que no teatro tudo é possível, justamente por não haver compromisso com o realismo. Homem faz mulher, mulher faz homem, jovens fazem velhos, velhos fazem jovens, gente faz bichos e até objetos se quiser. Costumo levar para eles(as) a ideia de que quem está no palco é a personagem, e não, você, fulaninho(a), até para desinibi-los(as). Falo da convenção de jogo de faz de conta que se estabelece entre cena e sala. Neste sentido, por que não, branco fazer negro? No teatro tudo é possível, desde que dentro do limite da "Ética da Solidariedade" (Boal, 2009, p. 17), base da árvore da Estética do Oprimido. O próprio espetáculo que eles iriam assistir, "Axé Nzinga", mostrava como um homem (Jonas Sales) poderia "representar" uma mulher (Rainha Ginga) cenicamente, a partir de seu lugar de fala, sem estereotipá-la, de forma respeitosa e ética. No entanto, a aluna apontou o caminho da representatividade, que para além de respeitar ou não respeitar, estereotipar ou não estereotipar, referiu-se à voz insubstituível de quem é socialmente silenciado(a), cerceado(a) do direito de falar.

\footnotetext{
12 O chamado black face surgiu por volta de 1830 da prática de homens brancos que se pintavam de preto de forma estereotipada e apresentavam para a aristocracia estadunidense as caricaturas representativas dos negros. Logo, tal prática foi adotada em várias partes do mundo e combatida pelos movimentos negros por entenderem que, além de representar pejorativamente os descendentes da diáspora africana, tal ato revela também a exclusão de negros dos palcos teatrais. Apesar de considerada racista, a prática ainda é realizada na atualidade (Costa, 2015).
} 
Neste sentido, Joice Berth (2018, p. 53) sinaliza:

[...] o lugar de fala coloca-se em uma posição estratégica de descortinador da bipolaridade social que ao mesmo tempo anseia pela igualdade em um sintoma confuso de crise ética, mas não se mostra disposta a olhar para seus acúmulos e questioná-los no sentido de promover um recuo em nome de uma transformação social completa e possível.

Reflito que o limiar entre representatividade e lugar de fala é uma linha tênue, que facilmente pode voltar-se contra, tornar-se um reforço de opressões, como ocorreu em minha sala de aula. Uma alternativa a essa problemática é apresentada por Bárbara Santos (2018), que atualiza o Teatro do Oprimido ao defender que, na cena fórum (conduzida pelo coringa), o espect-ator ${ }^{13}$ entre em cena ocupando o seu próprio lugar social e não o da protagonista. Por exemplo, numa cena de racismo em que uma mulher negra fosse abordada pelo segurança de um shopping que a acusasse injustamente de roubo, uma espectadora branca poderia entrar em cena como uma terceira personagem (mulher branca) e interferir a partir deste lugar: filmando a abordagem racista para posterior denúncia, por exemplo. Enfim, essa quebra de paradigmas contribuiu para eu reconhecer o meu próprio lugar social enquanto professora, que, no quesito racial, é de privilégio e, portanto, me cabe a escuta; bem como para buscar alternativas metodológicas que minimizem o risco desse reforço às opressões em sala de aula.

Nas turmas seguintes, acatei a sugestão da aluna acerca da representatividade e não houve mais black faces em cena/jogo. Reflito que ser professora, para além do constante aprendizado com os alunos, possibilita também que nos tornemos pessoas mais humanas, sensíveis e empáticas. Certamente o que essa aluna disse contribuiu para eu dar mais um passo na minha luta pessoal contra o meu próprio racismo estrutural. Exceto na turma em que houve a black face mal resolvida, chegamos a lugares interessantes de discussão. Nos debates em geral, eu questionava os lugares de poder pelo traje, bem como se o comportamento do personagem social correspondia à sua indumentária. Sobre o momento do jogo em que deveriam se ordenar a partir da reflexão sobre as relações de poder na sociedade contemporânea e organizar uma pirâmide social, uma aluna relatou:

No início eu fiquei revoltada quando o cachorro da rainha se colocou "maior" do que eu, que era mulher negra e pobre brasileira. Mas se a gente parar pra (sic) pensar, como deve ser a vida desse cachorro? Tudo do bom e do melhor... come e dorme, ganha carinho, não se preocupa com nada... e a vida dessa mulher? Violência de todo o tipo: racismo, machismo, sem saber o que botar na mesa pros (sic) filhos... fome, violência, sem remédios, sem hospital... Não precisava nem ser o cachorro da rainha da Inglaterra: tem muito cachorro no Brasil vivendo melhor que muita gente (aluna, 15 anos, 9o D).

Em duas turmas os(as) alunos(s) colocaram a rainha africana "acima" da rainha da Inglaterra na escala de opressão. Questionei sobre a visibilidade, representativi-

\footnotetext{
13 O termo diz respeito à noção de espectador "ativo", que intervém diretamente na cena, opinando ou atuando (literalmente), como proposto no teatro Fórum (Boal, 1996).
} 
dade, eurocentrismo e lugar de poder que ambas tinham nos livros de História e na mídia. Em ambas as turmas praticamente todos(as) os(as) alunos(as) já haviam ao menos ouvido falar em alguma rainha Elizabeth, mas ninguém conhecia a rainha Nzinga. Assim, nessas turmas, depois da discussão, propus que reordenassem a sequência a fim de corrigir essas distorções. Uma aluna negra, enquanto conduzia a personagem rainha Nzinga abaixo da rainha Elisabeth, desabafou: "não concordo que a Nzinga seja inferior só porque é africana e negra, mas entendi: o parâmetro não é o que eu penso, mas o preconceito da sociedade" (aluna, 15 anos, nono F). Ou seja, o jogo funcionou como desnudamento e denúncia às injustiças sociais veladas, que muitas vezes são silenciadas, menosprezadas. Para Boal (2009), "o Teatro do Oprimido quer ser um espelho mágico onde possamos, de forma organizada, politizada, transformar a nossa e todas as imagens de opressão que o espelho reflita" (2009, p. 190). Mas antes, para que seja possível esta transformação, é necessário olhar para o espelho e perceber as opressões à nossa volta.

Depois, o jogo foi repetido invertendo-se as duplas: quem era mestre figurinista se tornava personagem social e vice-versa. Mas agora o jogo propunha uma variação: não haveria mais papeizinhos com indicação e descrição de personagens, os(as) figurinistas deveriam criá-los somente a partir da indumentária. Isto é, os(as) mestres figurinistas tinham liberdade para criar personagens sociais como quisessem, a partir dos materiais disponíveis. A sequência do jogo permanecia a mesma até a discussão.

Em suma, os ensaios de preparação geraram vivências, leituras, partilhas, perguntas e reflexões interessantes, a fim de despertar a curiosidade sobre o espetáculo que seria assistido. Provocaram o debate ao mesmo tempo sobre temáticas do espetáculo Axé Nzinga e a indumentária teatral, numa perspectiva não dicotômica entre forma/conteúdo. Além disso, a mediação agregou ao trabalho de montagem teatral que vinha sendo desenvolvido, ampliando repertórios estéticos referentes às visualidades dos espetáculos.

\section{Mediação pós-espetáculo: Bate-papo com os artistas}

O sinal de saída tocou e praticamente todos os estudantes de Ensino Médio foram embora, enquanto que a maioria dos(as) aluno(as) de nono ano permaneceram no auditório, mesmo sem a obrigatoriedade. Pareciam estar muito curiosos(as) com algumas questões. $O$ ator sentou-se despojadamente na beirada do palco, se apresentou e disse que se interessava não somente por perguntas, mas pelo feedback crítico dos alunos, pois o espetáculo estava em constante alteração e a opinião e sugestões seriam bem-vindas. As perguntas e comentários não cessavam: "Por que você, sendo homem, quis representar uma mulher"? "Você se considera negro?" "Quem morreu na hora que o balão estoura"? "Você se incomodou com os comentários desrespeitosos do público no início?" "Quando você aponta o sapato pra gente como se fosse atirar, quem somos nós?" "Quanto tempo levou para preparar tudo?" Quantas pessoas estavam envolvidas em toda a montagem?" "É você que canta de verdade na cena dos navios negreiros? "A origem da palavra Ginga vem da rainha?" "Qual foi o motivo de todos os figurinos deixarem o seu peito nu? Além das perguntas, vários de- 
ram depoimentos: "Achei emocionante"; "No início eu não estava entendendo nada, mas depois do parto comecei a entender tudo"; "Nossa, você é muito bom! Deve ser muito difícil fazer um espetáculo inteiro, assim, sozinho"; "Adorei ver no palco cenas parecidas com jogos que fazemos em sala de aula, como na cena do balão e dos sapatos". Quase não fiz interferências, pois vi que o ator, que é também professor do curso de Licenciatura em Artes Cênicas na Universidade de Brasília, conduzia muito bem as respostas, sem ficar dando explicações sobre possíveis significados pretendidos, muitas vezes devolvendo as perguntas aos espectadores a fim de fomentar o diálogo. O nível de interesse, detalhamento e aprofundamento no bate-papo demonstrou uma efetividade do ensaio de preparação, que ao dilatar a visualidade da indumentária do espetáculo, provocou a leitura metafórica dos figurinos.

\section{Planejamento de mediação pós espetáculo: ensaios de prolongamento}

Nas aulas seguintes de cada turma seriam realizados "ensaios de prolongamento" (Desgranges, 2011), ou seja, mediação teatral pós-espetáculo na perspectiva da Pedagogia do Espectador. Como eu e os(as) graduandos(as) do PIBID não tivemos dessa vez tempo hábil de reunião para um novo planejamento coletivo, optei por conduzir e realizar os ensaios de prolongamento com as turmas completas (elencos e equipes de encenação reunidas), a fim de que todos os estudantes-espectadores de nono ano participassem desta etapa.

Para planejá-los, após ter assistido ao espetáculo na escola redigi previamente uma análise de Axé Nzinga à luz da Estética da Recepção (Iser, 1996), com o intuito de estimular a minha inventividade. Conforme o autor, "na leitura acontece a elaboração do texto, que se realiza através de um certo uso das faculdades humanas. Desse modo, não podemos captar exclusivamente o efeito nem no texto, nem na conduta do leitor; o texto é um potencial de efeitos que se atualiza no processo de leitura" (Iser, 1996, p.15).

Assim, o polo do texto e o polo dos(as) leitores(as), bem como a interação entre eles, formaram o esboço a partir do qual busquei analisar. Para além de um lugar assumido de leitura pessoal, observei os efeitos provocados nos espectadores - me incluindo como tal. Por essa perspectiva, levei em consideração o "critério de disponibilidade" (Hobsbaum apud Iser, 1996) dos(as) estudantes-espectadores(as), diante de seus processos históricos, seus horizontes de expectativas. Os critérios de análise não foram pré-estabelecidos mas suscitados pelo efeito estético da escrita cênica, no próprio ato de leitura. Isso porque na análise pela estética da recepção muda-se a pergunta: ao invés de questionar o que significa esta cena? pergunta-se: o que sucede com o leitor quando, com sua leitura, dá vida aos textos ficcionais? (Iser, 1996).

Considerei a minha leitura como qualquer outra, não tomada de modelo, mas apenas como ponto de partida reflexivo enquanto mediadora, para alimentar minha inventividade no ato de planejamento dos ensaios de prolongamento. Esses, por sua vez, também funcionaram apenas como ponto de partida pedagógico, pois a escuta no percurso reconduziria o trabalho nas diferentes turmas. 
Por fim, selecionei como ângulo de ataque inicial as narrativas temáticas do espetáculo, considerando os atravessamentos interpretativos/estéticos diversos que poderiam ser suscitados para, a partir daí, os(as) graduandos(as) do PIBID e os (as) alunos (as) de elenco retomarem seus ensaios afetados pela mediação realizada; bem como eu, com as equipes de encenação, poder dilatar os ensaios de prolongamento em sala de aula e imbricá-los ao processo de montagem para a Mostra de Teatro do Urso Branco.

\section{Mediação pós-espetáculo: Ensaios de Prolongamento}

No pátio da escola, com as turmas inteiras e os graduandos do PIBID como observadores participantes, propus o seguinte jogo: todos enfileirados lado a lado, apostariam uma corrida ${ }^{14}$. Mas antes do comando de partida, orientei que dessem um passo à frente cada vez que se identificassem com a afirmativa enunciada: dê um passo à frente se você nunca foi abordado pela polícia na rua; dê um passo à frente se você nunca foi acusado injustamente de roubo; dê um passo à frente se você vê sua cor de pele bastante representada na TV e nas revistas como padrão de beleza; dê um passo à frente se o seu cabelo é considerado "cabelo bom" e assim por diante. Em praticamente todas as turmas os alunos negros ficaram em desvantagem e, consequentemente, perderam a corrida.

Abri uma roda de conversa a partir a seguinte pergunta: o que esse jogo e o espetáculo "Axé Nzinga têm em comum"? Questões como racismo na atualidade e meritocracia foram debatidas em algumas turmas, políticas afirmativas para negros(as) como as cotas nas universidades, em outras. Conforme Boal (2009, p. 242), "a meta principal do T.O é, através dos meios estéticos, descobrir e conhecer a sociedade em que vivemos e, sobretudo, transformá-la. Sempre". Neste sentido, este jogo de corrida e posterior discussão contribuíram para desvelar o racismo e ao mesmo tempo, refletir sobre melhorias possíveis nas ações afirmativas de políticas públicas em seus contextos sociais.

Nos encontros seguintes, com elencos e equipes de encenação separados, a discussão também foi direcionada às escolhas estéticas do espetáculo e os(as) alunos(as) puderam fazer um link entre as suas escolhas criativas para a Mostra de Teatro que se aproximava. Por exemplo, o nono ano D se apropriou dos ensaios de desmontagem de Axé Nzinga como processo de montagem de "O Jovem e As Drogas"15 e incluiu uma citação de "Axé Nzinga" em uma cena que ocorria no pátio de uma escola (intitularam a escola de Colégio Nzinga, a partir de um jogo de improvisação realizado em ensaio de prolongamento do espetáculo).

\footnotetext{
14 Bárbara Santos (2018, p. 193) propõe uma variante deste jogo, intitulado de corrida "oportunidades iguais".

15 Dramaturgia de Marcondys França. O texto funcionou somente como ponto de partida (os processos criativos ocorreram nos ensaios de desmontagem/ montagem a partir de jogos de improvisação).
} 


\section{Considerações Finais}

O trabalho pedagógico teatral voltado para a formação de espectadores(as) na escola têm se mostrado um potente aliado para a ampliação de leitura de mundo dos(das) estudantes. Diante o contexto político sombrio ao qual estamos vivendo, infelizmente o simples fato de levar um espetáculo teatral profissional que trata das questões interseccionais de raça e gênero para dentro da escola já se configura como uma prática de resistência. Mas sabemos que a recepção teatral não garante a experiência estética e, por isso, buscamos potencializar a atuação do(a) leitor(a) e sua disponibilidade à produção de sentidos por meio de mediações teatrais em sala de aula. Este artigo detalhou as mediações pré e pós espetáculo que foram realizadas a partir do espetáculo "Axé Nzinga", de Jonas Sales. A análise dessas ações em processo de pesquisa me possibilitaram fazer algumas inferências, que não se configuram em "modelo" de ação para outros(as) professores(as), mas contribuem para a produção de conhecimento no campo da Pedagogia das Artes Cênicas.

As mediações teatrais, realizadas como "ensaios de preparação", "bate-papo pós espetáculo" e "ensaios de prolongamento" na perspectiva dos Ensaios de Desmontagem (Desgranges, 2011) foram agregadas ao trabalho que vinha sendo desenvolvidos pelo Método Recepcional (Bordini e Aguiar, 1993) desde o início do ano com as turmas de nono ano, somadas aos ensaios de resistência cultural (formação de espectadores sem espetáculo). Esse imbricamento possibilitou que o espetáculo e as mediações fossem parte do trabalho pedagógico da disciplina Teatro e não algo deslocado, como é comum ocorrer nas escolas (o teatro relacionado apenas a datas festivas). O fato de os(as) alunos(as) já possuírem alguma experiência com a linguagem teatral, pela disciplina escolar, certamente potencializou suas leituras, que se mostraram inventivas desde os ensaios de preparação.

Além disso, observei no bate-papo com o artista, que tanto a assiduidade, quanto o nível de curiosidade, interesse e aprofundamento nas perguntas foi maior com as turmas de nono ano, do que com os alunos de Ensino Médio que assistiram ao espetáculo. Assim, foi possível avaliar que as aulas de Teatro e as mediações pré-espetáculo afetaram positivamente o ato de leitura dos(as) estudantes de nono ano, que se mostraram mais disponíveis para se relacionar com a escrita cênica e mais inventivos(as) no ato de leitura de metáforas.

Por se tratar de um espetáculo que denunciava opressões de raça e gênero, dialogamos com a Estética do Oprimido a fim de desvelar opressões vivenciadas pelos(as) alunos(as) para que eles buscassem relações de seus cotidianos com o espetáculo assistido de forma autônoma. Nessa perspectiva, propusemos nas mediações situações em que os(as) estudantes-espectadores(as) produzissem e lessem metáforas relacionadas aos aspectos formais de indumentária teatral (imagem) sem dissociá-la das relações sociais de poder, tanto a partir da proposição de leituras inventivas em jogos de improvisação, quanto nas rodas de conversa. Em maior ou menor grau, todas as turmas criaram, leram, questionaram e discutiram as injustiças sociais interseccionais a partir da construção e da análise de uma pirâmide social hierárquica. Tendo como ponto de partida o figurino, opressões foram analisadas e desveladas a 
partir da leitura de cores (luz e pigmento), formas, simbologias, convenções visuais, estilos de época, croquis de personagens. Assim, o trabalho pedagógico atuou tanto na esfera social de formação para a cidadania quanto de conhecimento específico da linguagem teatral. Os temas desdobrados variaram entre racismo, racismo velado/estrutural, intersecções entre racismo, sexismo e LGBTfobia, colonialismo, cotas raciais, representatividade e lugar de fala, meritocracia, eurocentrismo e colorismo.

Além dos depoimentos de alunos(as) registrados no decorrer das mediações, o fato do artista ter sido questionado acerca do lugar de fala racial e de gênero demonstrou que as questões trabalhadas tanto nas mediações quanto no espetáculo contribuíram para um empoderamento e autonomia de discussão e questionamento sobre os temas. $\mathrm{O}$ artista disse que se autodeclara negro claro e, quanto a "fazer uma mulher", ele contou como o tema o solicitou a partir de uma repetição de acasos. Explicou que, inicialmente, ele dirigiria o espetáculo e assinaria a dramaturgia, mas que a representatividade seria dada a uma atriz negra. Porém, ao longo da concepção cênica ele começou a perceber que não queria que a rainha fosse "interpretada", mas desejava colocar a sua energia em cena. A partir de algumas experimentações, acabou assumindo a atuação, a fim de fazer uma homenagem às mulheres negras por meio da rainha Nzinga. Disse ainda que sabia que a questão seria problematizada - e era este o seu desejo: fomentar o debate.

Ao longo do percurso pedagógico das mediações, situações de racismo foram reveladas em duas turmas em sala de aula pela prática da black face. Essa situação, solucionada por uma aluna, me ensinou a importância da representatividade em sala de aula. Se no espetáculo "Axé Nzinga" o artista/professor/pesquisador conseguiu falar de Nzinga a partir do seu lugar de fala, em sala de aula me parece que há ainda um longo percurso a ser percorrido contra o racismo e o sexismo, o fundamentalismo e o fascismo, a começar pelo desvelamento das opressões que muitas vezes sequer são reconhecidas. Neste sentido, o caminho da representatividade apresentado pela aluna me parece ser uma alternativa ao mesmo tempo ética e viável na atual conjuntura, pois além de evitar que tais ridicularizações aconteçam, dá voz a quem é silenciado, contribuindo para o seu empoderamento. Por outro lado, Bárbara Santos (2018) propõe uma alternativa à representatividade em exercício-fórum que atualiza o Teatro do Oprimido e se aproxima à perspectiva de Jonas Sales acerca de se colocar em cena a partir do seu lugar de fala. Essa perspectiva será experimentada em práticas pedagógicas futuras.

As leituras inventivas por meio de jogos de improvisação (para além das rodas de conversa) contribuíram para superar outro desafio que surgiu ao longo do processo, de imbricar os ensaios de desmontagem nos processos de montagem em andamento para a Mostra de Teatro. É evidente que algumas turmas foram mais afetadas por "Axé Nzinga" do que outras, pois o grau de comprometimento dos diretores pibidianos, das turmas, o estágio em que se encontravam as montagens, o nível de desapego e abertura a alterações, o número de ensaios realizados em horário extracurricular etc. são apenas alguns exemplos das diversas variáveis presentes. No entanto, o ensaio de prolongamento de Axé Nzinga realizado com todas as turmas pôde ser continuado em aulas seguintes e direcionado para cada montagem em andamento, se transfor- 
mando em uma "via de mão dupla" entre o fazer e o fruir. Nesses ensaios, se estabeleceu uma tensão produtiva entre ver e fazer teatro, que culminou em citações de Nzinga na Mostra de Teatro dos Nonos Anos.

Em suma, para além da recepção de Axé Nzinga na escola, as mediações teatrais realizadas à luz das pedagogias citadas em tensão produtiva entre ver e fazer teatro se configuraram como caminhos de resistência contra o sucateamento das escolas públicas, a didatização dos saberes, as opressões, o fundamentalismo e o fascismo, entre outras possibilidades. Avalio que os objetivos tenham sido cumpridos, pois os alunos, de forma geral, efetuaram leituras inventivas e críticas do espetáculo, as relacionaram aos seus horizontes culturais, mostraram-se receptivos às leituras dos colegas e demonstraram desejo em assistir a outros espetáculos teatrais. Essas conquistas culturais apontam para o ato de leitura, ampliação de horizonte de expectativas, formação de espectadores e, conforme almejado, para a ampliação de leitura de mundo dos estudantes-espectadores.

\section{Referências}

AGUIAR, Vera Teixeira de e BORDINI, Maria da Glória. Literatura e Formação do leitor: alternativas metodológicas. Porto Alegre: Mercado Aberto, 1993.

BERTH, Joice. O que é empoderamento? Belo Horizonte: Letramento, 2018.

BOAL, Augusto. O arco íris do desejo: método Boal de teatro e terapia. Rio de Janeiro: civilização Brasileira, 1996.

BOAL, Augusto. A estética do oprimido: reflexões errantes sobre o pensamento do ponto de vista estético e não científico. Rio de Janeiro: Garamond, 2009.

COSTA, Alberto Roberto. A escolarização do corpus negro: processos de docilização e resistências nas teorias e práticas pedagógicas no contexto de ensino-aprendizagem de Artes Cênicas em uma escola pública do Distrito Federal. 2015. Universidade de Brasília, 2015: dissertação de mestrado.

DESGRANGES, Flávio. Mediação Teatral: anotações sobre o projeto Formação de Público. Urdimento, Florianópolis, n. 10, dez. 2008, p. 75-83.

DESGRANGES, Flávio. Pedagogia do Teatro: provocação e dialogismo. 3 ed. São Paulo: Hucitec, 2011.

DESGRANGES, Flávio. A Inversão da Olhadela: alterações no ato do espectador teatral. São Paulo: Hucitec, 2014.

DESGRANGES, Flávio. A pedagogia do espectador, 3a ed. São Paulo: Hucitec, 2015. 
FREIRE, Paulo. A importância do ato de ler: em três artigos que se complementam. São Paulo: Cortez, 1989.

FREIRE, Paulo. Pedagogia da Autonomia. São Paulo: Paz e Terra, 1996.

ISER, Wolfgang. O Ato da Leitura: uma teoria do efeito estético. Tradução de Johannes Kreschmer São Paulo: Ed.34,1996.

JAUSS, Hans Robert. A história da literatura como provocação à teoria literária. Trad. Sérgio Tellaroli. São Paulo: Ática, 1994 (série Temas, V. 36).

RIBEIRO, Djamila. O que é lugar de fala? Belo Horizonte: Letramento, 2017.

ROGOFF, Irit. Studying Visual Culture. In: MIRZOEFF, Nicholas (Ed.). The Visual Culture Reader. London: Routledge, 1998.

SANTOS, Bárbara. Percursos estéticos: abordagens originais sobre o Teatro do Oprimido. São Paulo: Padê editorial, 2018.

Recebido em: 13/11/2018 Aprovado em: 22/01/2019 